\title{
SISTEM KEWARISAN BILATERAL DITINJAU DARI PERSPEKTIF HUKUM ISLAM
}

\author{
Chamim Tohari \\ UNIVERSITAS MUAMMADIYAH SURABAYA \\ Email: amimzone@yahoo.co.id
}

\begin{abstract}
This study focuses on Hazairin's thoughts on the concept of bilateral inheritance, where the concept will be seen from the perspective of Islamic legal theory. The method used in this research is comparative-inductive analysis method. The points of problem to be studied in this research are: First, the concept of bilateral inheritance initiated by Hazairin; Secondly, the views of the ulama on the division of inheritance in a bilateral manner; and Third, the Islamic legal view of the concept of bilateral inheritance. The results of this study are: First, the concept of bilateral inheritance according to Hazairin is a concept of dividing heirs in kinship with the determination of his heirs by drawing his lineage through two lines of descent, namely the descendants of the father and through the descendants of his mother. Secondly, scholars differ on the law of inheritance division in a bilateral way, one group refuses and the other allows. And thirdly, the division of the heirs bilaterally in the author's view is not contrary to Islamic law.
\end{abstract}

Keywords : The Law of Islamic Inheritance, Bilateral, Islamic Law, Right of Being

\begin{abstract}
Abstrak
Penelitian ini menitikberatkan pada pemikiran Hazairin tentang konsep kewarisan bilateral, dimana konsep tersebut akan dilihat dari perspektif teori hukum Islam. Metode yang digunakan dalam penelitian ini adalah metode analisis comparativeinductive. Adapun poin permasalahan yang hendak dikaji dalam penelitian ini adalah: Pertama, konsep kewarisan bilateral yang digagas oleh Hazairin; Kedua, pandangan para ulama tentang pembagian kewarisan secara kekeluargaan (bilateral); dan Ketiga,pandangan hukum Islam tentang konsep kewarisan bilateral. Hasil penelitian ini adalah: Pertama, konsep kewarisan bilateral menurut Hazairin adalah suatu konsep pembagian harta waris secara kekeluargaan dengan penentuan ahli warisnya dengan cara menarik garis keturunannya melalui dua jalur keturunan, yakni keturunan ayah maupun melalui keturunan ibunya. Kedua, para ulama berbeda pendapat tentang hukum pembagian kewarisan secara kekeluargaan (bilateral), kelompok yang satu menolak dan kelompok lainnya membolehkan. Dan ketiga, pembagian harta waris secara bilateral dalam pandangan penulis tidak bertentangan dengan Hukum Islam.
\end{abstract}

Kata Kunci : Hukum Kewarisan Islam, Bilateral, Hukum Islam, Hak Makhluks 


\section{PENDAHULUAN}

Salah satu doktrin dalam hukum Islam yang bersifat qath'i - dalam arti mutawatir periwayatannya dan muhkam makna redaksi dalilnya - adalah tentang ketentuan pembagian kewarisan yang dalam fiqh klasik pembahasannya dikhususkan dalam kitab al-farâ'id. Berdasarkan kesepakatan jumhur ulama, dalil yang sifatnya qat'i wajib dipatuhi dan tidak boleh diselisihi. Selain itu, disepakati pula bahwa secara keseluruhan syariat Islam merupakan ajaran yang berorientasi kepada kemaslahatan, lebih-lebih ajaran yang bersumber dari dalil yang qath'i sebagaimana dijelaskan.

Kaitannya dengan konsep kemaslahatan dalam sistem hukum waris Islam yang bercorak patrilineal ini - yakni penentuan ahli waris dengan mengutamakan garis keturunan laki-laki - , kelompok muslim yang meyakini bahwa hukum kewarisan Islam mutlak mengandung kemaslahatan dalam keadaan apapun, berpendapat bahwa filsafat waris Islam menyebutkan bahwa pembedaan bagian si pewaris, laki-laki atau perempuan, tidaklah ditentukan oleh jenis kelamin. Tapi dalam pembedaan ini tersimpan hikmah-hikmah ketuhanan yang tidak bisa dijangkau oleh mereka yang menjadikan perbedaan tersebut sebagai satu bentuk diskriminasi terhadap kaum perempuan. ${ }^{1}$ Karena kepercayaan yang besar terhadap nilai keadilan dan kemaslahatan yang terkandung di dalam sistem hukum waris Islam tersebut membuat sebagian besar masyarakat muslim bersikap menerima doktrin fiqih waris sebagaimana adanya tanpa berfikir ulang tentang akibat-akibat baru yang akan muncul manakala mereka menerapkan sistem hukum waris Islam yang telah ada saat ini.

Berdasarkan hasil penelitian yang penulis lakukan, penulis menemukan permasalahan serius tentang sistem hukum kewarisan Islam dari sisi implementasinya dalam masyarakat muslim. Yakni dari satu sisi umat Islam meyakini bahwa sistem pembagian kewarisan dalam Islam adalah hukum yang diturunkan oleh Allah dan tidak boleh ditinggalkan, sementara di sisi lain banyak kaum muslim yang tidak menerapkan sistem kewarisan Islam dan beralih kepada pembagian kewarisan secara kekeluargaan (bilateral) demi terjaganya persaudaraan dan untuk menghindari saling

\footnotetext{
${ }^{1}$ Muhammad Imarah, Al-Gharb Wa al-Islam, (Sajadah Press, Yogyakarta, 2007), hlm. 247.
} 
permusuhan antar kelurga. Salah satu bukti dari fakta yang penulis paparkan adalah hasil penelitian yang dilakukan Fika Andriyani tentang Implementasi Hukum Waris Islam pada tokoh Muhammadiyah. Temuannya menjelaskan bahwa sebagian tokoh Muhammadiyah mengaku telah melakukan proses penerusan harta kekayaannya yang disebut waris. Penerusan harta kekayaan tersebut dilakukan pada anak-anak mereka dengan bagian sama rata dan dibagi habis. ${ }^{2} \mathrm{Hal}$ ini menurut hemat penulis dilakukan karena kekhawatiran orang tua akan perpecahan keluarga nanti setelah orang tua meninggal dunia.

Munawir Sjadzali. Mantan Menteri Agama zaman Orde Baru yang sekaligus pakar Hukum Islam ini mengatakan bahwa mereka yang tetap menghendaki pembagian harta waris 2:13 adalah kelompok yang ingin mempertahankan kedudukan kaum perempuan seperti pada zaman dimana surat al-Nisa' ayat 176 itu diturunkan, dimana kedudukan kaum perempuan pada masa itu secara umum masih jauh terbelakang dibandingkan dengan kaum laki-laki, sehingga kaum perempuan sangat sedikit mengambil peran dalam kehidupan bernegara dan berumah tangga. Mereka yang mempertahankan sistem pembagian kewarisan 2:1 menolak mempertimbangkan perubahan-perubahan sebagai akibat dari telah berubahnya situasi dan kondisi pada zaman sekarang ini dibandingkan dengan situasi pada zaman Nabi SAW. ${ }^{4}$ Menurutnya, pembagian warisan anak laki-laki mendapatkan dua kali lebih banyak dari anak perempuan itu tidak lagi mencerminkan semangat keadilan untuk masyarakat modern saat ini. Hal ini dibuktikan dengan banyaknya pelaksanaan pembagian harta oleh orang tua ketika masih hidup kepada anak-anaknya dengan jalan pembagian sama rata, demi menghindari agar tidak dikatakan melanggar Hukum Kewarisan Islam. Menurut Munawir Sjadzali hal seperti itu secara tidak langsung dapat dikatakan sebagai bentuk ketidakpercayaan pada keadilan Hukum Kewarisan Islam,

\footnotetext{
${ }^{2}$ Fika Andriyani, Implementasi Hukum Waris Islam pada Tokoh Muhammadiyah, (Jurnal Ulumuddin Cetakan Januari-Juni 2013, Fakultas Agama Islam, Universitas Muhammadiyah Malang), hlm. 199.

${ }^{3}$ Salah satu hal pokok yang tampak membedakan konsep kewarisan bilateral dengan konsep kewarisan Islam (patrilineal) adalah tentang ketentuan pembagian waris 2:1 ini. Dalam konsep kewarisan bilateral yang digagas Hazairin tidak didapati pembedaan pembagian antara laki-laki dan perempuan. Hal inilah yang oleh banyak kalangan dinilai bahwa sistem kewarisan bilateral tidak sejalan dengan hukum kewarisan Islam.

${ }^{4}$ Munawir Sjadzali, Ijtihad Kemanusiaan, (Jakarta: Paramadina, 1997), hlm. 6.
} 
yang mana jika dilihat dari segi akidah sikap seperti itu merupakan masalah serius dan berbahaya. ${ }^{5}$

Sebenarnya memang harus diyakini bahwa dalam hukum Allah, khususnya hukum dengan sandaran nash qath'i seperti ketentuan kewarisan dalam Islam, terdapat nilai-nilai keadilan. Akan tetapi nilai keadilan yang dimaksud tentunya tidak boleh terlepas dari konteks yang melatarbelakangi diturunkannya ayat yang dimaksud. Karena bisa jadi nilai-nilai keadilan pada zaman dimana ayat kewarisan diturunkan berbeda dengan nilai keadilan pada masa sekarang. Karena realitas sendiri menunjukkan bahwa peran perempuan pada masa sekarang dalam banyak keadaan mempunyai kewajiban yang sama dalam sebuah keluarga. Hal ini berbeda dengan peran perempuan pada masa lalu, lebih-lebih pada masa awal Islam. Sehingga sudah sepantasnya pembagian hak-haknya disesuaikan dengan peran yang diemban. Oleh sebab itu dalam pembagian warisan menurut hukum waris Islam pun dituntut untuk memperhatikan hak laki-laki maupun hak perempuan yang seimbang dan sama kuatnya. Bahkan tidak jarang dalam suatu keluarga ada sebagian yang menuntut hak yang sebanding dengan hak laki-laki. Realitas inilah yang saat ini banyak terjadi dikalangan masyarakat. Yakni realitas yang megganggap semua manusia mempunyak hak yang sama dihadapan hukum. Maka masyarakat pun telah merespon keinginan ini dengan menyamakan laki-laki dan perempuan sebagai ahli waris berdasarkan tanggung jawab yang diembannya.

Hazairin, seorang pakar hukum adat Indonesia ini telah lama melihat realitas permasalahan penerapan kewarisan Islam sebagaimana yang penulis jelaskan di atas. Karena itu kemudian ia menggagas satu bentuk sistem pembagian kewairsan yang lebih sesuai dengan kondisi masyarakat di Indonesia yang disebut sistem kewarisan bilateral (sistem kewarisan yang bercorak kekeluargaan). Dalam pandangan Hazairin, yang dimaksud dengan pembagian kewarisan secara bilateral adalah setiap orang dapat menarik garis keturunannya melalui keturunan ayah maupun melalui keturunan ibunya. Demikian pula dengan ayah dan ibunya, mereka juga dapat menarik garis

\footnotetext{
${ }^{5}$ Ibid, hlm. 8.
} 
keturunannya atas melalui dua jalur keturunan tersebut. Sehingga apabila dikaitkan dengan konsep kewarisan, maka pengertiannya adalah hak kewarisan yang berlaku dalam dua jalur keturunan atau kekerabatan, baik dari jalur ayah maupun dari jalur ibu. ${ }^{6}$ Di Indonesia masyarakat dengan karakter bilateral adalah yang paling dominan. Sehingga apabila ditinjau dari sisi praktisnya, teori Hazairin tampaknya benar-benar sesuai dan menemukan tempatnya apabila diterapkan di Indonesia.

Namun demikian, masih banyak dikalangan umat Islam dan juga akadimisi yang berpendidikan tinggi di Indonesia yang masih meragukan - kalau tidak boleh dikatakan mengingkari - bahwa sistem kewarisan bilateral adalah sistem yang sejalan dengan syariat Islam. Bahkan selama penelitian yang penulis lakukan, penulis sempat menjumpai adanya pemikiran seorang akademisi yang menganjurkan dilakukannya helat hukum dengan cara membagi harta waris sebagaimana ketentuan kitab fara'id, kemudian setelah itu dilakukan islah dengan cara meminta kerelaan pihak keluarga yang mendapat bagian lebih banyak dari yang lainnya untuk membagi harta warisan kembali secara sama rata. Hal ini dilakukan selain agar tidak dikatakan bahwa pembagian warisan tersebut tidak sesuai dengan syariat Islam, juga untuk menghindari perpecahan keluarga akibat pembagian harta waris yang tidak sama rata. Sejauh pengetahuan penulis, meskipun dengan dalih kemaslahatan pun perbuatan melakukan helat hukum menyangkut pembagian harta waris eperti ini tidak pernah dilakukan oleh para ulama mujtahid pada masa lalu.

Bertolak dari latar belakang realitas permasalahan tersebut isu hukum yang diangkat dalam penelitian ini adalah adanya pembagian kewarisan secara kekeluargaan yang seringkali dianggap tidak sesuai dengan syari'ah Islam oleh umat Islam, tetapi dalam waktu yang bersamaan realitas menunjukkan bahwa hukum kewarisan Islam tidak lagi sejalan dengan semangat keadilan masyarakat Indonesia, sehingga tidak sedikit umat Islam yang meninggalkannya. Atas dasar ketertarikan penulis kepada model sistem pembagian kewarisan yang berbasis kekeuargaan tersebut, penelitian ini hendak mengkaji tentang konsep kewarisan bilateral dalam

\footnotetext{
${ }^{6}$ Sudarsono, Hukum Waris dan Sistem Bilateral, (Jakarta: Rineka Cipta, 1991), hlm. 174-175.
} 
kacamata Hukum Islam dengan cara melakukan analisis konsep kewarisan bilateral dengan menggunakan landasan teori Hukum Islam. Beberapa persoalan yang hendak mencari jawaban dari beberapa pertanyaan berikut: Pertama, bagaimana konsep kewarisan bilateral dalam pandangan Hazairin selaku penggagasnya?; Kedua, bagaimana pandangan para ulama tentang pembagian kewarisan secara kekeluargaan (bilateral); dan Ketiga, bagaimana pandangan hukum Islam tentang konsep kewarisan bilateral tersebut? Metode komparatif dan induktif digunakan sebagai metode analisis guna menyimpulkan arah penelitian dan menghasilkan poin-poin sebagai jawaban dari pokok masalah yang dikaji.

\section{PEMBAHASAN}

\section{Konsep Kewarisan Bilateral}

Sejauh ini apabila dilihat dari corak penerapannya, dapat dikatakan bahwa secara umum sistem kewarisan yang diterapkan oleh masyarakat di Indonesia terdiri dari tiga bentuk, yakni: Pertama, sistem Patrilineal, yakni penentuan ahli waris dengan mengutamakan garis keturunan laki-laki; Kedua, sistem Matrilineal, yakni penentuan ahli waris dengan mengutamakan garis keturunan perempuan; dan ketiga, sistem Bilateral atau Parental, yakni penentuan ahli waris dengan mengambil kedua garis keturunan laki-laki dan perempuan. Apabila mengikuti pendapat Hazairin, sistem patrilineal dinisbatkan kepada suku Batak, sedangkan sistem matrilineal dinisbatkan kepada suku Minangkabau, dan sistem bilateral (parental) dinisbatkan kepada suku Jawa. ${ }^{7}$

Kewarisan bilateral adalah sistem penetapan ahli waris dengan cara menarik dari dua garis keturunan, garis keturunan ibu dan bapak tanpa adanya pengutamaan salah satu garis keturunan. Sehingga berbeda dengan sistem patrilineal dan matrilineal, kedudukan antara laki-laki dan perempuan tidak dibedakan dan dianggap setara dalam sistem kewarisan bilateral ini. Sistem kewarisan dengan cara ini telah lama diterapkan oleh suku Jawa, Aceh, Kalimantan, Ternate dan Lombok. Sistem yang ketiga

\footnotetext{
${ }^{7}$ Hazairin, Hukum Kewarisan Bilateral Menurut al-Qur'an dan Hadis, Jakarta:TP, 1982), hlm. 37.
} 
ini menjadi isu sentral pemikiran pembaharuan Hazairin dalam bidang Hukum Kewarisan Islam.

Sistem ini merupakan kesimpulan Hazairin setelah mengkaji beberapa ayat dalam al-Qur'an, diantaranya surat al-Nisa' ayat 23 dan 24, akhirnya ia menyimpulkan bahwa sistem kewarisan berbasis kekeuargaan (bilateral) adalah sejalan dengan syariat Islam. Pandangan Hazairin tersebut tampak berbeda dengan apa yang telah dirumuskan oleh para ulama terdahulu dalam kitab-kitab fiqh klasik yang menetapkan Hukum Kewarisan Islam berdasarkan sistem patrilineal. Bahkan lebih jauh Hazairin menegaskan bahwa al-Qur'an maupun Hadis keduanya tidak mengajarkan sistem kekerabatan maupun kewarisan dengan corak unilateral, yakni sistem kemasyarakatn dan kewarisan seperti patrilineal dan matrilineal, tetapi justru keduanya mengajarkan sistem kemasyarakatan berbasis kekeluargaan, sehingga konsekwensinya hukum kewarisan pun seharusnya berbasis kekeluargaan. ${ }^{8}$

Berbeda dengan sistem kewarisan yang umumnya dijelaskan dalam kitab-kitab fiqh Sunni yang membagi ahli waris ke dalam ashab al-furudh, ashobah dan dzawi alarham, Hazairin dengan sistem kewarisan bilateralnya membagi ahli waris ke dalam dzawi al-furudh, dzawi al-qarabah ${ }^{9}$ dan mawali. ${ }^{10}$

Perbedaan pandangan antara Hazairin dengan jumhur ulama ini berawal dari pendapat Hazairin yang tidak menerima konsep ashobah dalam sistem kewarisan Islam konvensional. Dalam pandangan Hazairin, konsep ashobah hanya terdapat dalam masyarakat unilateral, yakni masyarakat yang menganut sistem kewarisan patrilineal atau matrilineal saja. Sedangkan dalam masyarakat dengan corak bilateral (parental) - seperti masyarakat Jawa - tidak mengenal istilah tersebut. Dalam masyarakat dengan corak patrilineal seperti masyarakat Arab di Timur Tengah dan masyarakat Batak di Indonesia, mereka hanya mengenal garis keturunan dari pihak laki-laki (bapak) saja. Begitu pula dengan masyarakat dengan corak matrilineal, mereka

\footnotetext{
${ }^{8}$ Ibid, hlm. 2.

${ }^{9}$ Abdul Halim, Hazairin dan Pemikirannya Tentang Pembaharuan Hukum Kekeluargaan Islam, dalam Penelitian Jurnal Agama, no. 18, vol. Vii, tahun 1998, hlm. 136.

${ }^{10}$ Hazairin, Hukum Kewarisan Bilateral, hlm. 36.
} 
hanya mengenal garis keturunan dari pihak perempuan (ibu) saja seperti dalam masyarakat Minangkabau. Adapun masyarakat dengan corak bilateral (parental) mereka menggunakan dua garis keturunan (bapak dan ibu) untuk menentukan ahli waris.

Menurut hemat penulis, penolakan Hazairin terhadap konsep ashobah dengan memaknai ulang dalil-dalil yang menjadi dasar ditetapkannya ahli waris ashobah oleh para ulama fiqh adalah dalam rangka usaha Hazairin untuk menyesuaikan pemikirannya tentang sistem kewarisan bilateral dengan dalil-dalil al-Qur'am dan hadis agar pemikirannya tentang kewarisan bilateral tersebut tidak bertentangan dengan nash syar'i. Dan hal tersebut bukan hal yang terlarang dalam konteks ijtihad. Selain itu harus dipahami bahwa penolakan Hazairin terhadap konsep ashobah tersebut adalah bentuk perjuangannya agar konsep kewarisan bilateral menjadi bagian dari hukum kewarisan Islam sehingga tidak bertentangan dengan hukum kewarisan adat dan dapat diterima oleh masyarakat yang beragama Islam khususnya di Indonesia.

\section{Prinsip Dasar Sistem Kewarisan Bilateral}

Pemikiran Hazairin tentang sistem kewarisan bilateral mengandung beberapa prinsip pokok yang membedakannya dengan pemikiran hukum kewarisan Islam pada umumnya. Adapun prinsip yang paling penting yang menjadi fokus pembahasan penulis adalah prinsip bahwa ahli waris laki-laki memiliki kedudukan yang sama dengan ahli waris perempuan.

Ahli waris perempuan dalam sistem bilateral memiliki derajat kedudukan yang sama dengan laki-laki sehingga dapat menutup ahli waris pada kelompok keutamaan yang lebih rendah. Misanya, selama masih ada anak, baik itu laki-laki maupun perempuan, maka saudara si pewaris baik yang laki-laki maupun yang perempuan sama-sama terhalang untuk mendapatkan bagian harta waris (mahjub). Jadi intinya dalam kewarisan bilateral, selama masih ada keturunan (baik laki-laki maupun perempuan) maka secara mutlak meng-hijab saudara untuk menjadi ahli waris. Prinsip yang digunakan Hazairin ini kemudian berimplikasi pada pemikirannya tentang 
konsep kalalah. Yakni seseorang yang meninggal dan tidak meinggalkan keturunan laki-laki maupun perempuan. Penhertian ini berbeda dengan pengertian kalalah menurut sistem hukum patrilineal seperti yang ditetapkan oleh mazhab Ahlussunnah waljamaah, yang memahami kalalah sebagai seseorang yang mati tanpa meninggalkan keturunan laki-laki atau ayah, dan sebagai akibatnya saudara dapat mewaris bersama anak perempuan.

Sistem hukum kewarisan bilateral hasil ijtihad Hazairin ini secara tegas tidak membedakan garis keturunan laki-laki dan perempuan. Keduanya memiliki kekuatan hukum yang sama, mereka baik laki-laki maupun perempuan memiliki kesamaan hak untuk mendaptkan harta warisan dari kedua garis keturunan orang tua dan kerabatnya. Untuk prinsip yang pertama ini, yakni prinsip kesetaraam ini Hazairin mendasarkan pendapatnya pada al-Qur'an surat al-Nisa' ayat 7. Prinsip lainnya adalah prinsip yang menyatakan bahwa kekerabatan laki-laki memiliki kekuatan yang sama dengan garis kekerabatan perempuan dalam pewarisan; serta prinsip kedudukan Mawali setara dengan kedudukan orang yang digantikan. ${ }^{11}$ Namun kedua prinsip terakhir ini tidak menjadi pokok pembahasan penulis.

\section{Sistem Kewarisan Bilateral Ditinjau Dari Perspektif Hukum Islam \\ Perdebatan Ulama Tentang Kontekstualisasi Hukum Kewarisan Islam}

Sebelum melakukan tinjauan secara utuh terhadap sistem kewarisan bilateral dalam sudut pandang Hukum Islam, terlebih dahulu penulis hendak membahas tentang perdebatan para pakar hukum dan ulama tentang wajib tidaknya menerapkan Hukum Kewarisan Islam berdasarkan konsep kewarisan patrilineal atau konsep kewarisan Islam konvensional. Secara umum para pakar hukum Islam terbagi dua kelompok dalam menyikapi penerapan sistem kewarisan Islam, ada yang mengharuskan mengikuti produk fiqh yang disusun para ulama terdahulu dengan sistem patrilineal, dan ada yang membolehkan pembaharuan dibidang ilmu fara'id

\footnotetext{
${ }^{11}$ Ibid, hlm. 728.
} 
meskipun ketentuan jumlah bagian ahli waris tersebut sudah disebutkan oleh nash yang sifatnya qath'i

Kelompok pertama, bersandar pada - setidaknya sepanjang yang penulis temukan selama penelitian ini - tiga alasan:

Pertama, falsafah kewarisan Islam. Berdasarkan falsafah kewarisan Islam, seorang laki-laki berkewajiban memikul tanggung jawab biaya hidup atas perempuan (istri) beserta anak-anaknya, disamping biaya hidup saudara perempuannya apabila saudara perempuannya tersebut belum menikah. Karena itulah saudara perempuan apabila dibandingkan dengan saudaranya yang laki-laki yang mewarisi dua kali lipat dari bagian warisnya, memiliki hak istimewa yaitu ditanggung biaya hidupnya. Oleh karena itu bagian warisan saudara perempuan si laki-laki tersebut dianggap sebagai harta yang tersimpan yang dibawa oleh saudara laki-lakinya untuk dijaga dan dimanfaatkan untuk kebutuhan saudara perempuan tersebut. Pendapat seperti yang demikian diungkapkan oleh Muhammad Imarah. Ia menganggap bahwa ketentuan bagian laki-laki dua kali bagian perempuan adalah hikmah ketuhanan yang tak banyak diketahui oleh banyak orang. Namun demikian ia juga mengakui bahwa hakekatnya ketentuan pembagian warisan bagian laki-laki dua kali bagian perempuan adalah ketentuan yang tidak mutlak harus dilaksanakan, tetapi itu adalah ketetapan yang pelaksanaannya hanya pada waktu dan kndisi tertentu saja yang sangat terbatas. ${ }^{12}$

Ali al-Shobuni dalam kaitannya dengan pembagian warisan 2:1 menyatakan bahwa itu adalah keadilan syariah Islam, dimana perempuan itu selalu dicukupi kebutuhannya baik itu oleh suaminya, ayahnya, anak lali-lakinya, maupun oleh para kerabatnya. Selain itu ada beberapa alasan mengapa perempuan menerima bagian lebih sedikit dalam pandangan al-Shobuni, yakni: Pertama, karena perempuan tidak dibebani menafkahi keluarganya, sedangkan laki-laki dibebani menafkahi keluarga dan bahkan kerabatnya; Kedua, karena laki-laki memikul tanggung jawab yang lebih besar daripada perempuan dalam hidupnya; Ketiga, karena laki-laki diwajibkan member mahar, tempat tinggal, pakaian dan makan untuk keluarganya; dan Keempat, karena biaya-

\footnotetext{
${ }^{12}$ Muhammad Imarah, Al-Gharb Wa al-Islam, hlm. 246-250.
} 
biaya pendidikan dan kesehatan semuanya ditanggung oleh laki-laki. Menurut alShobuni justri syariah Islam memberikan kesejahteraan yang tinggi kepada kaum perempuan karena ia tetap mendapat bagian harta warisan tanpa memikul tanggung jawab. ${ }^{13}$

Kedua, konsep keadilan berimbang. Konsep keadilan distributif atau dalam istilah lain disebut dengan keadilan berimbang adalah keseimbangan antara hak dan kewajiban dengan dikaitkan dengan peranan dan kegunaan. Keadilan berimbang ini oleh sebagian pakar kewarisan Islam menjadi salah satu dari prinsip atau asas dalam hukum kewarisan Islam. Menurut pemahaman kelompok yang mewajibkan sistem kewarisan patrilineal ini, keadilan tidak mesti selalu harus diwujudkan dengan kesamaan bagian, tetapi keadilan harus dikaitkan dengan proporsi tanggung jawab seorang ahli waris antara yang satu dengan lainnya. Pendapat ini diantaranya dikemukakan oleh Sayid Qutub. Beliau menyatakan bahwa kaitannya dengan kelipatan bagian laki-laki atas bagian perempuan dalam kewarisan harus dirujuk pada watak atau karakteristih seorang laki-laki dalam kehidupan dimana kaum laki-laki selalu memiliki tanggung jawab yang lebih besar daripada kaum perempuan. Jadi perbedaan jumlah bagian warisan dalam pandangan Sayid Qutub hanyalah perbedaan yang muncul karena karakteristik tanggung jawab mereka yang mempunyai konsekwensi logis dalam pembagian harta waris. ${ }^{14}$

Menurut kelompok yang sepakat bahwa hukum kewarisan Islam patrilineal harus diterapkan berdasarkan pada konsep keadilan berimbang ini diantara alasannya karena di dalam aturan hukum kewarisan tersebut benar-benar terkandung nilai keadilan, baik keadilan tersebut dapat dipahami atau tidak. Kelompok ini meyakini bahwa penetapan bagian laki-laki dua kali dibanding bagian perempuan dalam kewarisan bukanlah bentuk kezaliman, tetapi karena berhubungan dengan perbedaan kadar hak dan kewajiban antara laki-laki dan perempuan. Selain itu haruslah dipahami bahwa pemberian warisan berbeda dengan pemberian kasih sayang dalam keluarga

\footnotetext{
${ }_{14}^{13} \mathrm{http} / / /$ elc.stain-pekalongan.ac.id/. Diakses pada 20 Desember 2016.

${ }^{14}$ Sayid Qutub, Al-Adalah al-Ijtima'iyah fi al-Islam, terjemahan Afif Muhammad, (Bandung: Pustaka, 1994), hlm. 71.
} 
yang menuntut keadilan dalam arti kesamaan baik dalam segi kualitas maupun kuantitasnya. ${ }^{15}$

\section{Ketiga, kesepakatan ulama bahwa nash yang bersifat qath'i tsubut dan dalalah-nya wajib diikuti.}

Hukum syar'i yang berdasarkan pada dalil yang bersifat qath'i ats-tsubût qath'i addalâlah merupakan hukum syar'i yang berdasarkan dalil yang tingkat validitas dalil tersebut mencapai tingkat seratus persen dan tidak mengandung pemahaman lebih dari satu pemahaman. Sehingga hukum yang dihasilkan sudah pasti keberlakuannya dan tidak lagi memerlukan ijtihad. Oleh karena hukum tersebut demikian nyata dalilnya, baik validitas maupun maknanya, maka sudah semestinya wajib diikuti. ${ }^{16}$

Kelompok ini menegaskan bahwa nash qath'i tidak dapat dikalahkan dengan pendapat para cendikiawan kontemporer yang dengan landasan teori seperti HAM, kesetaraan gender dan keadilan universal yang sarat dengan kepentingan realitas untuk kemudian mengubah ketentuan dalam hukum kewarisan Islam 2:1 dengan formulasi baru 1:1. Menurut paham kelompok ini sangat penting mempertahankan konsep kewarisan 2:1 mengingat ketentuan tersebut berasal dari dalil yang qath'i tsubut (pasti periwayatannya) dan qath'i dalalah (pasti maknanya dan tidak memungkinkan adanya makna lain). Diantara yang menganut pendapat ini adala ulama kotemporer Muhammad Ali Al-Shobuni. ${ }^{17}$

\footnotetext{
${ }^{15}$ Maulana Hamzah, Persepsi Aktivis Gender Indonesia Terhadap Sistem Pembagian Harta Waris 2:1 Dalam Hukum Kewarisan Islam, Skripsi Fakultas Syariah UIN Syahid Jakarta tahun 2010, hlm. 32-33.

${ }^{16}$ Menurut al-Shatibi sebagaimana dikutip oleh Quraish Shihab, bahwa sedikit sekali - bahkan hampir dikatakan tidak ada - satu teks keagamaan baik dalam al-Qur'an maupun Hadis yang secara berdiri sendiri dapat dipahami memiliki interpretasi tunggal dan tidak ada kemungkinan arti lain untuk teks tersebut. Hal ini menurutnya disebabkan karena untuk mencapai kepastian baik sumber maupun maknanya dibutuhkan dalil lain yang menjelaskan kepastian tersebut. Sementara dalil-dalil yang dimaksud yang dapat menjelaskan kepastian yang dimaksud juga bersifat relatif. Sehingga tidak mungkin sesuatu yang mendasarkan pada yang relatif dapat menjadi absolut. Lebih jauh ia mengatakan bahwa menetapkan interpretasi tunggal bagi satu teks keagamaan memerlukan sekumpulan argumentasi pendukung, dan hal inilah antara lain yang menyebabkan ajaran Islam yang bersifat absolute sangat sedikit. Lihat Quraish Shihab, Membumikan Al-Qur'an, (Bandung: Mizan, 1994) hlm.220-221. Pernyataan tersebut apabila dikaitkan dengan surat al-Nisa' ayat 11 yang berbicara tentang bagian laki-laki dua kali bagian perempuan maka dapat dikatakan bahwa surat tersebut adalah kelompok yang sedikit tersebut, yakni kelompok ajaran Islam yang absolut, karena kejelasan transmisi dan kejelasan maknanya yang tidak lagi dapat ditafsirkan dengan makna lainnya.

${ }^{17}$ http://digilib.uin-suka.ac.id3471/, diakses pada 22 Desember 2016.
} 
Adappun mereka yang tidak mewajibkan pembagian harta waris secara patrilineal seperti ketentuan-ketentuan yang termaktub dalam kitab-kitab fiqh konvensional salah satunya adalah Munawir Sjadzali, mantan Menteri Agama RI pada masa Orde Baru. menurutnya perubahan kedudukan dan fungsi perempuan pada masa modern seharusnya menjadi pertimbangan bagi pengembangan hukum kewarisan Islam pada masa sekarang. Sehingga produk hukum kewarisan terdahulu yang sudah tidak relevan lagi dengan situasi dan kondisi riil di masyarakat tidak terus menerus menjadi acuan dalam memutuskan perkara kewarisan. Selain itu, kaum perempuan pada masa dimana fiqh klasik disusun belum memainkan peranan seperti sekarang ini. Dahulu kaum perempuan mustahil menjadi pemimpin negara, tetapi tidak untuk zaman modern. Juga hal-hal yang berkaitan dengan kesaksian, segi intelektual dan peranannya di masyarakat, seorang perempuan masa kini lebih unggul daripada lakilaki. Hal-hal seperti ini seharusnya dapat menjadi pertimbangan dalam menyikapi hukum kewarisan klasik yang bercorak patrilineal. ${ }^{18}$

Selanjutnya beliau menegaskan bahwa pembagian harta warisan dengan ketentuan bahwa laki-laki mendapat dua kali dari jumlah bagian perempuan untuk masa sekarang ini sudah tidak lagi mencerminkan semangat keadilan dalam masyarakat di Indonesia. Hal ini menurut beliau terbukti dengan banyaknya penyimpangan yang bahkan dilakukan oleh orang-orang yang memahami ilmu syariah dengan melakukan pembagian harta kekayaannya kepada anak-anaknya semenjak dirinya masih hidup secara sama rata, dengan tujuan agar tidak dianggap tidak melakukan pembagian kewarisan berdasarkan hukum Islam. Dalam pandangan beliau perbuatan seperti ini sama halnya dengan mereka tidak lagi percaya dengan keadilan dalam hukum waris Islam. Karena jika mereka percaya dengan keadilan yang terkandung dalam hukum waris Islam, tentunya mereka tidak akan melakukan pembagian harta dengan cara penerusan sebagaimana dijelaskan. Bahkan beliau menegaskan bahwa dari segi aqidah, sikap seperti demikian itu adalah masalah serius dan berbahaya bagi keimanan seseorang. Karena itu seharusnya hukum kewarisan

\footnotetext{
${ }^{18}$ Munawir Sjadzali, Ijtihad Kemanusiaan, hlm. 6-7.
} 
Islam yang ada haruslah dimaknai sebagai produk hukum yang responsive dengan konteks zaman yang menyertainya. Karena kedudukan hukum kewarisan Islam yang demikian, maka menurut beliau tidak ada kewajiban untuk terus menerus mengikuti hukum kewarisan Islam klasik yang bercorak partilineal tersebut. Selain itu dalam pandangan beliau, terdapat banyak keganjilan dalam sistem kewarisan Islam produk klasik tersebut. Misalnya dalam hukum pernikahan Islam tidak dibedakan kedudukan dan peranan antara laki-laki dan perempuan, tetapi justru mengapa dalam hukum kewarisan ada perbedaan jumlah bagian yang diterima. Padahal antara hukum pernikahan dan hukum kewarisan adalah dua hal yang tidak boleh dipisahkan antara satu dengan lainnya. ${ }^{19}$

Pendapat yang lain tentang kebolehan meninggalkan sistem kewarisan Islam bercorak patrilineal dikemukakan oleh Muhammad Daud Ali, pakar hukum asal Aceh ini secara terang memasukkan prinsip bilateral sebagai salah satu asas hukum kewarisan dalam Islam disamping beberapa prinsip lainnya seperti prinsip ijbari, prinsip individual, dan prinsip keadilan berimbang. ${ }^{20}$ Selain itu beliau menyatakan bahwa semestinya umat Islam di Indonesia diberi kebebasan untuk menyesuaikan atau mengembangkan hukum kewarisan Islam sesuai dengan apa yang dibutuhkan oleh masyarakat muslim di Indonesia. ${ }^{21}$ Diantaranya kebebasan melakukan modifikasi hukum kewarisan Islam dari prinsip patrilineal kepada prinsip bilateral. Karena yang demikian itu lebih rasional dan lebih dapat diterima oleh masyarakat muslim di Indonesia.

Pendapat berikutnya tentang tidak wajibnya menerapkan sistem kewarisan Islam dengan corak patrilineal dikemukakan oleh Musdah Mulia. Menurutnya, sebagai sesama hamba Allah, tidak ada perbedaan antara laki-laki dan perempuan.keduanya berpotensi menjadi hamba yang ideal yang dalam istilah al-Qur'an adalah orang yang bertaqwa. Dalam pandangan Musdah Mulia, salah satu tuntunan agama yang paling

\footnotetext{
${ }^{19} \mathrm{Ibid}, \mathrm{hlm} 8$.

${ }^{20}$ Muhammad Daud Ali, Hukum Islam: Pengantar Ilmu Hukum dan Tata Hukum Islam di Indonesia, (Jakarta: Rajawali Press, 2007), hlm. 141-142.

${ }^{21}$ Ibid, hlm. 333.
} 
pokok dan mendasar adalah keharusan menghormati sesama manusia tanpa melihat jenis kelamin, ras, gender, suku bangsa, apalagi agama. Karenanya setiap agama selalu mengajarkan dua aspek mendasar, yakni ajaran ketuhanan (aqidah) dan ajaran kemanusiaan (muamalah). ${ }^{22}$ Kaitannya dengan pemikiran Musdah Mulia tentang konsep keadilan dengan hukum kewarisan Islam, ia menuntut agar hukum kewarisan Islam tidak membeda-bedakan antara bagian laki-laki dengan perempuan atas dasar keadilan gender tersebut. Tafsir Musdah Mulia tentang ayat-ayat kewarisan tampaknya sangat kental dengan konsep keadilan gender yang selalu mencita-citakan terwujudnya derajat kaum perempuan setara dengan kaum laki-laki.

Husein Muhammad, dalam kajiannya tentang ketentuan pembagian harta warisan 2:1 mengatakan bahwa ketentuan tersebut hendaknya dipahami dalam konteks sosial bangsa Arab. Menurutnya pola pembagian waris seperti itu sebenarnya adalah pola pembagian yang sangat maju dan proporsional pada konteks tersebut.hal ini karena disamping sustem kekerabatan yang dianut bangsa Arab adalah sistem patrilineal, juga berkaitan erat dengan struktur sosial dan ekonomi yang berlaku pada saat itu. Dalam sistem kekeluargaan bangsa Arab laki-laki dikonstruksikan sebagai entitas publik dengan fungsi umum. Selama berabad-abad lamanya bangsa Arab menem-patkan lakilaki sebagai produsen penghasil ekonomi, sementara perempuan ditem-patkan dalam fungsi reproduksi, yakni melayani kebutuhan seksual laki-laki, mengan-dung, melahirkan, menyusui dan merawat rumah. Dalam konteks sosial seperti itu perempuan tidak berkewajiban bekerja mencari nafkah baik di dalam maupu diluar rumah. ${ }^{23}$

Husein Muhammad menegaskan, dalam kondisi kultur bangsa Arab sebagaimana disebutkan, seluruh kebutuhan hidup pokok perempuan seperti sandang, pangan dan tempat tinggal menjadi kewajiban suami. Bahkan dalam kitab-kitab fiqh klasik ditemukan bahwa istri juga tidak berkewajiban membersihkan rumah, mencari air, dan menyusui anaknya sendiri. Namun demikian tidak berarti bahwa bayi yang terlahir tidak disusui oleh ibunya. Bayi tersebut tetap harus diberi air susu ibu, tetapi

\footnotetext{
${ }^{22}$ Siti Musdah Mulia, Muslimah Reformis: Perempuan Pembaharu Keagamaan, (Bandung: Mizan, 2005), hlm. 2129.

${ }^{23}$ Husein Muhammad, Waris Laki-laki dan Perempuan, dalam www.rahima.or.id, diakses pada 22 Desember 2016.
} 
tidak harus dari air susu ibu kandungnya. Karena itu apabila ibu kandungnya bersedia menyusui anaknya tetapi sang ibu meminta upah untuk itu, maka bapak atau suami dari ibu yang menyusui tersebut wajib memberinya upah. Karena itulah, menurut Husein Muhammad dengan pembagian kerja seperti itu maka pemberian waris kepada kaum perempuan dengan pola 2:1 bukan saja sangat proporsional, tetapi lebih dari itu sangat menguntungkan kaum perempuan. ${ }^{24}$

Dalam pandangan Husein Muhammad, hukum Islam adalah doktrin yang elastis dan dapat berubah sesuai kebutuhan zaman, selain juga berkeyakinan bahwa apa yang ditetapkan berdasarkan tradisi (yang tidak bertentangan dengan syariah) adalah sama statusnya dengan apa yang ditetapkan berdasarkan nash atau teks. Artinya, ketentuan yang telah ditetapkan oleh nash apabila sudah tidak sejalan dengan semangat keadilan pada suatu konteks sosial tertentu, maka hendaknya tidak lagi harus dipertahankan keberlakuannya. Demikian pandangan Husein Muhammad tentang sistem kewarisan Islam yang bercorang patrilineal dengan pola 2:1.25

Muhammad Sahrur, dengan teori hududnya (teori batas) mengemukakan alasan kemungkinan anak perempuan bisa mendapatkan harta warisan setara dengan bagian anak laki-laki dengan menggunakan metode pemikiran hukum yang ia sebut sebagai teori hudud atau teiru batas. Menurutnya, surat al-Nisa' ayat 11 menegaskan batasan bagian dimana laki-laki dan perempuan dapat menerima warisan, yakni bagi lai-laki diterapkan batas maksimal dua kali bagian perempuan, dan bagi perempuan diterapkan batas minimal yakni satu dibanding dua dari bagian laki-laki. Sehingga berdasarkan ketentuan tersebut batas maksimal yang diterima laki-laki adalah dua (66,6\%) sedangkan batas minimal yang diterima perempuan adalah satu $(33,3 \%)$. Adapun di antara kedua batas tersebut menjadi lahan ijtihad para ulama untuk menetapkan bagian warisan antara laki-laki dan perempuan sesuai dengan konteks yang dihadapi, dengan mempertimbangkan kadar peranan dan tanggung jawab masing-masing dalam sebuah keluarga. Sehingga dapat dikatakan bahwa ketentuan

\footnotetext{
${ }^{24}$ Ibid.

${ }^{25}$ Ibid.
} 
bagian dua dibanding satu dalam pandangan Muhammad Sahrur bukanlah hal yang mutlak untuk diterapkan dalam setiap keadaan. Karena sangat memungkinkan dalam suatu kondisi tertentu seorang perempuan dapat mendapat bagian yang sama dengan bagian laki-laki, atau bahkan dapat pula mendapat lebih banyak dari laki-laki. ${ }^{26}$

Menurut Muhammad Sahrur, para mujtahid memiliki tugas untuk menentukan komposisi bagian kelompok anak laki-laki dan anak perempuan sesuai dengan ketentuan situasi dan kondisi yang berlaku pada suatu masyarakat tertentu yang didukung oleh bukti-bukti materiil-statistik, bukan berdasarkan pada prasangka atau perkiraan (apalagi perasaan) semata. Apabila dipandang perlu lanjut Sahrur maka pembagian sama rata pun dapat dibenarkan. ${ }^{27}$ Sahrur mengatakan bahwa bila dalam suatu masyarakat berlaku kebiasaan dimana perempuan juga ikut menanggung beban ekonomi keluarga (istri ikut bekerja), maka bagian kelompok anak perempuan bergantung pada sumbangannya kepada keluarga atau disesuaikan dengan kondisi sosial yang berlaku. ${ }^{28}$

\section{ANALISIS KRITIS METODOLOGIS}

Apabila dianalisis pendapat yang mewajibkan pembagian kewarisan berdasarkan hukum kewarisan Islam yang telah ada, yakni hukum kewarisan patrilineal, maka dapat penulis tegaskan adanya beberapa kelemahan metodologis dengan tidak dilakukannya beberapa langkah dalam proses ijtihad sebagai berikut:

\section{Penerapan Hukum Yang Tidak Melihat Konteks Sosial Yang Dihadapi.}

Penetapan hukum dalam Islam semestinya mempertimbangkan konteks sosial yang dihadapi. Apabila unsur ini tidak dipenuhi, kemungkinan besar hukum yang dihasilkan dari ijtihad yang mengabaikan konteks sosial akan sulit diterima orang, bahkan bisa jadi mengakibatkan kesalahan fatal. Beberapa kaidah fiqh yang dapat dijadikan landasan pemikiran ini diantaranya adalah:

\footnotetext{
${ }^{26}$ Untuk lebih jelasnya tentang teori hudud yang berkaitan dengan konsep kewarisan dalam perspektif Sahrur dapat diakses dalam karya Muhammad Sahrur, Al-Kitab wa al-Qur'an Qira'at Muashirah, (Libanon: Syirkah alMathbu'ah, 2000), hlm. 458-603.

${ }^{27}$ Ibid, hlm. 459.

${ }^{28} \mathrm{Ibid}$, hlm. 602-603.
} 


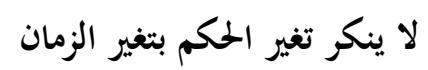

"Tidak diingkari bahwa perubahan hukum (dilakukan) karena perubahan zaman." 29

Kaidah ini adalah kaidah yang sudah umum dan terkenal dalam teori pembuatan dan peruabahn hukum Islam. Diskursus tentang elastisitas dan fleksibilitas hukum Islam senantiasa dikaitkan dengan sejauh mana hukum Islam itu bisa bergerak dinamis seiring dengan perubahan zaman dan tempat. Syari'ah sebagai sumber dan prinsip serta nilai universal tidaklah berubah, tetapi pemahaman dalam bentuk fiqh bisa saja berubah dan berkembang. Contoh yang sering diungkapkan sebagai justifikasi atas kaidah ini adalah keberanian Umar bin Khattab untuk tidak memotong tangan pencuri, tidak memberikan zakat kepada orang yang baru masuk Islam, dan tidak melaksanakan hukuman pengasingan dalam kasus zina seorang perawan. Sahabatsahabat Nabi yang lain dan ulama pada masa berikutnya juga melakukan hal yang sama dengan apa yang dilakukan oleh Umar. Dalam hubungannya dengan ini, Ibn Rusyd menyatakan bahwa sesungguhnya ada beberapa hukum Allah yang sebabsebabnya tidak pernah ada pada masa awal Islam, maka ketika sebab-sebabnya diketahui, dibuatlah hukum dengan berdasarkan pada sebab-sebab itu. ${ }^{30}$

Kaidah tersebut tentu bukan merupakan kaidah yang mutlak berlaku pada semua hukum. Hukum-hukum tertentu yang berkaitan dengan masalah ibadah seperti hukum wajibnya sholat, puasa, serta hukum haram dari perbuatan-perbuatan maksiat seperti mencuri, merampok, dan berzina adalah hukum tetap yang tidak berubah kecuali dalam keadaan terpaksa (darurat).

Kaidah lainnya yang berkaitan dengan perubahan hukum adalah;

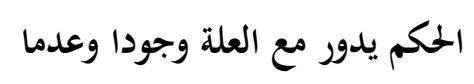

“Hukum itu bergantung pada ada atau tidaknya 'illat hukumnya."31

\footnotetext{
${ }^{29}$ Majallah al-Ahkam al-Adliyah, pasal 39.

${ }^{30}$ Ahmad Imam Mawardi, Fiqh Minoritas: Evolusi Maqashid al-Syari'ah dari Konsep ke Pendekatan, (Yogyakarta: LKIS, 2010), hlm. 146-147.

${ }^{31}$ Muchlis Usman, Kaidah-kaidah Ushuliyah dan Fiqhiyah, (Jakarta: Raja Grafindo Persada, 2012), hlm. 20.
} 
Yakni pelaksanaan hukum adalah karena adanya 'illat yang menyertainya. Misalnya dibolehkannya melakukan jamak qasar adalah karena adanya illat hukum bepergian, atau perintah bersuci ketika berhadas (kecil maupun besar), maka perintah bersuci tersebut tetap ada sepanjang 'illatnya yakni karena adanya hadas itu masih ada.

Kaidah berikutnya adalah;

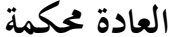

“Adat (kebiasaan) dapat dijadikan hukum." 32

Islam datang dengan membawa nilai-nilai ketuhanan dan nilai-nilai kemanusiaan. Ketika itulah nilai-nilai kemanusiaan tersebut bertemu dengan nilai-nilai adat kebiasaan di masyarakat. Di antara nilai adat ada yang sejalan dengan prinsip syariah, dan diantara yang lain ada yang tidak sejalan. Disinilah kemudian ulama membagi adat menjadi dua, yakni adat shahihah dan adat fashihah. Dalam kontek adat kebiasaan dapat menjadi hukum, yang dimaksud tentulah adat shahihah, adat yang tidak bertentangan dan sejalan dengan syariah. Hal ini apabila dikaitkan dengan adat kekeluargaan dalam masalah pembagian warisan, tentulah adat dengan pola bilateral tersebut tidak bertentangan dan bahkan sejalan dengan semangat keadilan yang hendak diwujudkan sebagai salah satu tujuan universal hukum Islam.

Beberapa kaidah fiqh di atas seharusnya menjadi pertimbangan kelompok yang mewajibkan kewarisan Islam patrilineal harus diterapkan di semua kondisi dan zaman. Menurut hemat penulis, kaidah-kaidah sebagaimana disebutkan di atas dapat digunakan sebagai dasar perubahan hukum kewarisan Islam dari bentuknya yang patrilineal ke bentuk yang lebih sesuai dalam konteks Indonesia, yakni bilateral. Karena apabila disepakati, 'illat dari hukum kewarisan pada bagian laki-laki dua kali bagian perempuan adalah adanya tanggung jawab, yakni adanya tanggung jawab laki-laki yang lebih besar dari perempuan. Karena itu, ketika pada masa sekarang tanggung jawab antara laki-laki dan perempuan sudah sama besarnya, maka seharusnya hukum tersebut juga berubah sesuai 'illat hukumnya.

\footnotetext{
${ }^{32}$ Abu Ishaq al-Shatibi, Al-Muwafaqat fi Ushul al-Syariah, (Kairo: t.p., t.th.), jilid 2, hlm. 296.
} 


\section{Tidak Membedakan Antara Maksud-Maksud Yang Mapan (Tetap) Dengan Wasilah- wasilah Yang Dapat Berubah.}

Hal ini penting karena washîlah atau media perantara juga diperlukan eksistensinya sama seperti maqâshid. Hanya saja, washîlah ini diperlukan bukan karena eksistensinya, malainkan hanya sebagai perantara terwujudnya hal lain yang dibutuhkan keberadaannya, yaitu maqâshid itu sendiri. ${ }^{33}$ Seringkali dalam ketentuan hukum keterkaitan antara maqâshid dan washâ'il ini tampak dengan jelas, tetapi tidak tertutup kemungkinan terlihat samar dan serupa. Kegagalan membedakan antara keduanya akan mengakibatkan kesalahan dalam proses ijtihad yang akan menghasilkan ketentuan hukum yang salah pula. ${ }^{34}$

Dalam bukunya yang lain, yakni Imam al-Shatibi's Theory of the Higher Objectives and Intents of Islamic Law, al-Raysûnî menyebutkan empat panduan dasar yang harus dipahami dalam melakukan ijtihad yang mirip dengan empat hal di atas, tetapi lebih praktis dan operasional: (1) teks dan aturan hukum tidak terpisah dari tujuannya, (2) mengkombinasikan prinsip-prinsip universal dengan dalil yang digunakan untuk kasus tertentu, (3) mencapai kemaslahatan dan mencegah kemafsadatan, dan (4) mempertimbangkan hasil akhir. ${ }^{35}$

Pandangan al-Raysûnî di atas sesungguhnya menitikberatkan pada urgensi keterkaitan 'illat, dalil, dan kemaslahatan sebagai tujuan hukum. Pandangan ini paralel dengan kaidah yang dikemukakan oleh al-Shâthîbî dalam sisi keinginan menampakkan wajah hukum Islam yang berorientasi pada kemaslahatan sebagai tujuan syari'at. Pandangan-pandangan tersebut dielaborasi lebih luas oleh Jamâl al-Dîn 'Athiyyah dan Jasser Auda yang menyampaikan beberapa dasar tata kerja metodologis ijtihad yang dikaitkan dengan ushûl fiqh dan qawấ'id al-figh. Keterkaitan tiga hal inilah yang perlu

\footnotetext{
${ }^{33}$ Ahmad al-Raysûnî, Al-Fikr al-Maqâshidî Qawâ'iduĥ̂ wa Fawâ'iduĥu, (Ribath: Mathba'ah al-Najah, 1999), hlm. 77-80.

${ }^{34}$ Ibid, hlm. 88. Lihat pula Yûsuf al-Qaradhâwî, Kayfa Nata'âmal ma'a al-Sunnah al-Nabawiyyah Ma'alim wa Dhawâbith, (Virginia: IIIT, 2005).

${ }^{35}$ Ahmad al-Raysûnî, Imam al-Shatibi's Theory of the Higher Objectives and Intents of Islamic Law, (London Washington: IIIT, 2005), hlm. 336-362.
} 
dikaji lebih jauh ketika hendak mengungkap tentang bagaimana sesungguhnya ijtihad ini.

Kaitannya dengan pendapat ulama yang mewajibkan diterapkannya hukum kewarisan Islam dengan corak patrilineal, maka dapat dikatakan bahwa kelompok ini dalam membangun pendapatnya tidak melihat mana maksud yang tetap dan mana wasilah yang dapat berubah dalam konteks hukum kewarisan tersebut. Penulis melihat bahwa tujuan pokok dari ketentuan pembagian harta warisan yang disebutkan oleh nash adalah untuk terwujudnya keadilan. Adapun aturan-aturan yang menentukan besar kecilnya bagian setiap ahli waris adalah wasilah untuk terwujudnya keadilan tersebut. Jadi, ketika wasilah yang disebutkan oleh nash dalam kondisi tertentu sudah tidak lagi dapat mewujudkan keadilan, maka wasilah tersebut dapat dutangguhkan pelaksanaannya dan mengganti dengan wasilah yang lain yang lebih dapat menjamin terwujudnya keadilan dalam pembagian harta waris.

\section{Memahami Nash Qath'i Hanya Dari Aspek Linguistik Dan Transmisinya Saja.}

Apabila dilihat dengan teori hukum, ada hukum yang ideal yang dapat diberlakukan pada semua konteks sosial, kondisi dan zaman. Namun ada juga hukum yang realistis yang artinya hukum tersebut hanya dapat diberlakukan pada konteks sosial dan masa tertentu, namun tidak dapat diterapkan pada semua tempat dan zaman yang berbeda. Hukum ideal dalam istilah ushul fiqh modern disebut hukum yang qath'i. sedangkan hukum realistis disebut hukum yang zhanni. Dalam konteks ini, ayat-ayat dan hadis yang berbicara tentang hukum kewarisan sudah jelas bermuatan keadilan local dan temporal sehingga bersifat zhanni, buka qath'i. karena itu, bagaimana berinteraksi dengan dalil zhanni adalah dengan cara tidak menganggapnya sakral sehingga menangguhkan penerapannya demi kemaslahatan yang lebih jelas adalah hal yang seharusnya dilakukan.

\section{Tidak Melihat Maksud-Maksud Syari'ah (Maqashid Al-Syari'ah)}

Kesalahan yang lain dari pendapat yang mewajibkan pemberlakuan hukum kewarisan patrilineal menurut analisis penulis adalah mereka tidak menghubungkan 
ayat-ayat yang menjelaskan ketentuan bagian warisan tersebut dengan tujuan-tujuan yang diinginkan ayat-ayat tersebut. Tujuan yang paling tampak dari ketentuanketentuan pembagian warisan adalah untuk terwujudnya keadilan dan proporsionalitas berdasarkan fungsi dan peranan antara laki-laki dan perempuan dalam kehidupannya masing-masing, dengan menjadikan besar kecilnya peranan dalam hidup antara laki-laki dan perempuan sebagai 'illat dari hukum kewarisan. Artinya, besar kecilnya bagian warisan bergantung para besar kecilnya fingsi dan peranan masing-masing. Apabila besari kecilnya peranan berubah, maka besar kecilnya bagian warisan juga harus berubah. Hal ini yang tidak dipertimbangkan oleh mereka yang memberlakukan ayat-ayat kewarisan secara mutlak pada kondisi apapun tanpa melihat tujuan-tujuan pokok ayat-ayat waris tersebut.

\section{PERSPEKTIF HUKUM ISLAM TENTANG LEGALITAS SISTEM KEWARISAN BILATERAL}

Menurut hemat penulis, pembahasan masalah hukum kewarisan berbasis kekeluargaan (bilateral) ini berhubungan dengan macam-macam hak dalam konteks kajian hukum keluarga Islam. Pembagian hak kepada beberapa kategori adalah penting dalam rangka memastikan mana sengketa mengenai hak yang bisa diselesaikan secara damai atau dengan kata lain bisa diselesaikan secara kekeluargaan dan masalah mana yang tidak bisa diselesaikan secara kekeluargaan yang dalam bahasa fiqh disebut islah.

Dalam kajian hukum Islam, hak terbagi menjadi beberapa kelompok. Pengelompokan tersebut pada dasarnya adalah pecahan dari dua kategori umum, yaitu (1) Hak Allah yang juga disebut hak umum; dan (2) Hak makhluk yang juga disebut sebagai hak perorangan. Perlu di ingat bahwa adanya kategorisasi hak kepada Allah dan hak makhluk atau hak hamba bukanlah sebuah pemisahan secara tajam. Karena pada prinsipnya dalam keyakinan umat Islam semua hukum yang diturunkan Allah adalah hak mutlak Allah dalam arti wajib ditaati. Kategorisasi tersebut antara lain dalam rangka membedakan mana hukum yang dalam penyelesaiannya terdapat jalan penyelesaian alternatif selain hukum yang sudah jelas tertulis (misalnya dengan 
penyelesaian melalui islah secara kekeluargaan) dan mana yang tidak punya alternatif sehingga tidak bisa diselesaikan kecuali seperti ketentuan yang jelas tertulis.

Para pakar ushul fiqh seperti Ali Hasabalah, pakar hukum Islam Mesir ini menjelaskan bahwa hak-hak Allah atau hak umum sepenuhnya terletak di tangan penguasa untuk melaksanakan hukuman duniawi atas diri pelanggarnya. Dan yang perlu dicatat dalam hal ini adalah bahwa tidak seorangpun - meskipun penguasa itu sendiri - yang dapat menggugurkan atau memaafkan orang yang melanggarnya. Orang yang melakukan kejahatan zina atau pencurian misalnya, apabila telah terbukti dan mencukupi syarat-syaratnya, haruslah dituntut dan dikenakan sanksi dan tidak seorangpun yang berhak membebaskannya dengan cara memaafkannya. ${ }^{36}$

Pendapat Ali Hasabalah tersebut sejalan dengan pendapat pakar hukum Islam lainnya seperti Abdul Wahab Khalaf. Menurutnya tidak ada alternatif bagi mukallaf kecuali melaksanakan hukum yang telah ditentukan oleh nash selama masalahnya berhubungan dengan hak Allah. Tidak seorangpun yang mempunyai kewenangan untuk mengugurkan dengan cara islah atau memaafkan. Karena menurutnya seorang mukallaf (orang yang dibebani hukum) hanya berhak memaafkan suatu pelanggaran jika pelanggaran yang dimaksud berhubungan dengan hak pribadinya. Oleh sebab itu seseorang tidak berhak memaafkan orang yang tidak sholat, tidak puasa, zakat dan haji, dan tidak pula berhak menggugurkan sanksi-sanksi hukum atas kejahatan zina atau sanksi perampokan dan pembunuhan, karena semua itu adalah pelanggaran yang tidak berhubungan dengan hak seseorang. Begitu pula tidak ada perdamaian dalam masalah-masalah yang hukumannya sudah ditentukan oleh nash. ${ }^{37}$

Adapun taklif yang berkaitan dengan hak makhluk atau hak hamba, dalam fiqh Islam ketentuan-ketentuan hukum yang berhubungan dengan bidang ini apabila dilanggar sepenuhnya terserah kepada pemilik hak yang dilanggar, apakah ia akan menuntut atau memaafkannya. Begitu juga tentang penyelesaian hak dalam bentuk ini bisa diselesaikan secara damai atau secara kekeluargaan. Misalnya seseorang yang

\footnotetext{
${ }^{36}$ Lihat selengkapnya dalam buku Ali Hasabalah, Ushul al-Tasyri' al-Islami, (t.tp.: t.p., t.th.), hlm. 3-59.

${ }^{37}$ Abdul Wahab Khalaf, Ilm Ushul al-Fiqh, (Kuwait: Dar al-Qatam, t.th), hlm. 44-57.
} 
memecahkan kaca mobil orang lain, terserah kepada pihak yang punya mobil, apakah ia akan meminta ganti rugi atau merelakannya. Demikian pula seseorang yang berpiutang kepada pihak lain, maka yang berpiutang bebas memilih antara tetap menagih piutangnya atau membebaskannya tanpa perlu membayarnya.

Konsep hak dalam hukum Islam sebagaimana dijelaskan di atas apabila dikaitkan dengan hukum kewarisan, maka akan timbul pertanyaan berikut: "Hak seseorang untuk mewarisi harta orang yang meninggal sesuai ketentuan yang ditetapkan nash, apakah termasuk kategori hak Allah atau hak makhluk/hak hamba?". Jawaban dari pertanyaan tersebut adalah penting, karena dengan jawabah itu permasalahan - dalam masalah pembagian kewarisan secara bilateral atau kekeluargaan dalam pandangan hukum Islam - ini akan terjawab.

Apabila merujuk pada pendapat seorang ulama kontemporer, yakni Muhammad Abu Zahrah, beliau menegaskan bahwa hak seseorang untuk mewarisi harta peninggalan pewarisnya yang telah meninggal dunia termasuk ke dalam kategori hak hamba atau hak perorangan secara murni. Beliau menganalogikan hak untuk mewarisi dengan hak untuk menagih piutang dan masalah-masalah lainnya yang berhubungan dengan kepemilikan harta. Setelah menegaskan bahwa hak mewarisi adalah hak makhluk atau hak hamba secara murni, Abu Zahrah menjelaskan lebih lanjut bahwa melanggar hak makhluk adalah sebuah kezaliman. Allah tidak menerima taubat seseorang yang memakan hak hamba, kecuali yang berbuat zalim tersebut membayar hak itu kepada pemiliknya atau digugurkan oleh pemilik atau dimaafkan olehnya. Hak semacam ini tidak lain adalah untuk memelihara kemaslahatan perorangan. Oleh karena itu hak seperti ini dapat digugurkan oleh pemilik hak. ${ }^{38}$

Berdasarkan pendapat Syeikh Abu Zahrah di atas dapat dikatakan bahwa pembagian harta warisan apabila setiap pihak ahli waris secara rela membaginya secara kekeluargaan, maka dapat dibagi secara kekeluargaan atau bilateral sesuai dengan kesepakatan setiap pihak yang terkait dengan pembagian harta waris tersebut. Bahkan berdasarkan hal tersebut adalah sah apabila ada di antara ahli waris yang merelakan

\footnotetext{
${ }^{38}$ Muhammad Abu Zahrah, Ushul al-Fiqh, (Kairo: Dar al-Fikr al-Arabi, t.th.), hlm. 6-25.
} 
atau mengugurkan haknya dalam pembagian harta warisan itu untuk diserahkan kepada ahli waris yang lain. Jadi, kesimpulannya berdasarkan sudut pandang hukum Islam, harta warisan boleh dibagikan secara kekeluargaan atau bilateral, dimana hal tersebut mendapat pengakuan dalam Kompilasi Hukum Islam pasal 183.

Ada berbagai alasan yang mungkin mendorong seseorang untuk mengugurkan haknya. Misalnya ia adalah seorang yang berhasil dalam kehidupan ekonominya bila dibandingkan dengan ahli waris yang lain. Dengan demikian secara suka rela ia memberikan haknya kepada pihak yang kurang berhasil kehidupan ekonominya. Atau, ia menyadari bahwa yang paling banyak mengurus orang tuanya semasa hidupnya adalah salah seorang dari ahli waris yang ditinggalkan. Sehingga wajar jika ahli waris yang seorang itu dibagi lebih banyak dari harta peninggalan pewaris yang telah meninggal dunia.

Dari penjelasan di atas dapat dipahami bahwa adanya izin dalam ajaran Islam untuk membagi harta warisan secara kekeluargaan atau dengan sistem bilateral. Dengan adanya izin itu berarti pembagian seperti itu tetap bersifat Islami. Kesimpulan ini diharapkan menjadi penjernih dari anggapan pihak yang berpendapat bahwa pembagian harta waris secara kekeluargaan itu tidak sesuai dengan hukum Islam.

Walaupun pembagian harta warisan secara bilateral adalah sah menurut pandangan Muhammad Abu Zahrah, namun praktik pembagiannya itu sendiri harus memenuhi syarat-syaratnya. Diantara syarat terpentingnya adalah keharusan adanya kecakapan bertindak secara hukum yang didasarkan atas kerelaan penuh dari pihakpihak yang terllibat dalam pembagian warisan. Hal ini diwajibkan, karena dalam pembagian harta waris secara bilateral mungkin ada sebagian pihak yang perlu mengorbankan atau mengugurkan haknya baik sebagian ataupun keseluruhannya. Masalah penguguran hak milik - karena berkaitan dengan menghilangkan hak miliki seseorang - berhubungan erat dengan masalah kecakapan untuk bertindak secara hukum. Artinya penguguran suatu hak milik baru dianggap sak apabila dilakukan oleh seseorang secara sukarela dan sedang mempunyai kecakapan bertindak. Sebaliknya, pengguguran suatu hak milik dianggap tidak sah apabila dilakukan oleh seseorang 
yang tidak punya atau sedang kehilangan kecakapan untuk bertindak secara hukum. Misalnya disebabkan oleh adanya suatu kondisi yang mengganggu kebebasannya untuk menentukan sikap. ${ }^{39}$

\section{KESIMPULAN}

Dari hasil kajian di atas, beberapa poin yang dapat disimpulkan antara lain: Pertama, konsep kewarisan bilateral dalam pandangan Hazairin adalah suatu konsep pembagian harta waris secara kekeluargaan dengan penentuan ahli warisnya melalui cara menarik garis keturunannya melalui dua jalur keturunan, yakni keturunan ayah maupun melalui keturunan ibunya. Artinya hak kewarisan berlaku dalam dua jalur keturunan atau kekerabatan, baik dari jalur ayah maupun dari jalur ibu. Kedua, para ulama berbeda pendapat tentang pembagian kewarisan secara kekeluargaan (bilateral). Kelompok yang satu menolak pembagian kewarisan yang menyelisihi dalil qath'i tentang ketentuan pembagian harta waris, sedangkan kelompok lainnya membolehkan dengan alasan kontekstualisasi hukum Islam dapat dibenarkan ketika nash sudah tidak relevan dengan kebutuhan umat Islam. Ketiga, pembagian harta waris secara bilateral atau kekeluargaan dapat dibenarkan dari perspektif hukum Islam karena masalah kewarisan menyangkut hak manusia. Dan ketika seseorang melepaskan haknya karena adanya kesadaran tanpa paksaan, maka hukumnya mubah untuk memiliki hak yang terlepas dari pemiliknya.

\footnotetext{
${ }^{39}$ Masalah kecakapan bertindak secara hukum dalam kajian ushul figh disebut dengan ahliyah al-ada'. Ahliyah alada' adalah kecakapan seseorang untuk dibebani melakukan ibadah dan untuk bertindak secara hukum. Dengan adanya kecakapan bertindan seseorang baru dapat disebut sebagai mukallaf. Mukallaf adalah seseorang yang dibebani untuk melaksanakan segala bentuk taklif (kewajiban) dan segala tindakannya akan diperhitungkan oleh hukum Islam. Yang dijadikan dasar kecakapan bertindak secara hukum adalah akal. Jadi ada atau tidaknya kecakapan, sempurna atau tidaknya kecakapan tergantung kepada akal seseorang. Untuk lebih jelasnya kajian tentang ahliyah ini dapat merujuk kepada kitab Mustafa Ahmad Zerka, Al-Madkhal al-Fiqh al-Amm, (Damsyiq: Dar al-Qalam, 2004), jilid 2, hlm. 779-819.
} 


\section{DAFTAR PUSTAKA}

Ali, Muhammad Daud. Hukum Islam: Pengantar Ilmu Hukum dan Tata Hukum Islam di Indonesia, Jakarta: Rajawali Press, 2007.

Al-Qaradhâwî, Yûsuf. Kayfa Nata'âmal ma'a al-Sunnah al-Nabawiyyah Ma'alim wa Dhawâbith, Virginia: IIIT, 2005.

Al-Raysûnî, Ahmad. Al-Fikr al-Maqâshidî Qawâ'iduhî wa Fawấ'iduhû, Ribath: Mathba'ah al-Najah, 1999.

Imam al-Shatibi's Theory of the Higher Objectives and Intents of Islamic Law, London - Washington: IIIT, 2005.

Al-Shatibi, Abu Ishaq. Al-Muwâfaqât fî Ushûl al-Syarîah, Kairo: t.p., t.th., jilid 2.

Andriyani, Fika. Implementasi Hukum Waris Islam pada Tokoh Muhammadiyah, (Jurnal Ulumuddin Cetakan Januari-Juni 2013, Fakultas Agama Islam, Universitas Muhammadiyah Malang).

Hacak, Hasan. Hak, dalam DIA, Istanbul: ISAM Yayincilik, 1989.

Hamzah, Maulana. Persepsi Aktivis Gender Indonesia Terhadap Sistem Pembagian Harta Waris 2:1 Dalam Hukum Kewarisan Islam, Skripsi Fakultas Syariah UIN Syahid Jakarta tahun 2010.

Hasabalah, Ali. Ushûl. Al-Tasyrî̀' al-Islâmî, t.tp.: t.p., t.th.

Hazairin. Hukum Kewarisan Bilateral Menurut al-Qur'an dan Hadis, Jakarta:TP, 1982.

Imarah, Muhammad. Al-Gharb Wa al-Islam, Sajadah Press: Yogyakarta, 2007.

Khalaf, Abdul Wahab. Ilm Ushûl al-Figh, Kuwait: Dar al-Qatam, t.th.

Mawardi, Ahmad Imam. Fiqh Minoritas: Evolusi Maqashid al-Syari'ah dari Konsep ke Pendekatan, Yogyakarta: LKIS, 2010.

Muhammad Abu Zahrah, Ushûl al-Fiqh, Kairo: Dar al-Fikr al-Arabi, t.th.

Mulia, Siti Musdah. Muslimah Reformis: Perempuan Pembaharu Keagamaan, Bandung: Mizan, 2005.

Qutub, Sayid. Al-Adalah al-Ijtima'iyah fi al-Islam, terjemahan Afif Muhammad, Bandung: Pustaka, 1994. 
Sahrur, Muhammad. Al-Kitab wa al-Qur'an Qira'at Muashirah, Libanon: Syirkah alMathbu'ah, 2000.

Shihab, Quraish. Membumikan Al-Qur'an, Bandung: Mizan, 1994.

Sjadzali, Munawir. Ijtihad Kemanusiaan, Jakarta: Paramadina, 1997.

Sudarsono. Hukum Waris dan Sistem Bilateral, Jakarta: Rineka Cipta, 1991.

Usman, Muchlis. Kaidah-kaidah Ushuliyah dan Fiqhiyah, Jakarta: Raja Grafindo Persada, 2012.

Zerka, Mustafa Ahmad. Al-Madkhal al-Figh al-Amm, Damsyiq: Dar al-Qalam, 2004.

\section{Sumber dari internet}

http://elc.stain-pekalongan.ac.id/, diakses pada 20 Desember 2016.

http://digilib.uin-suka.ac.id3471/, diakses pada 22 Desember 2016.

Muhammad, Husein. Waris Laki-laki dan Perempuan, dalam www.rahima.or.id, diakses pada 22 Desember 2016. 